DOI: https://doi.org/10.47405/mjssh.v6i8.970

\begin{tabular}{|c|c|}
\hline 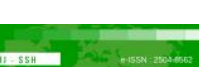 & Malaysian Journal of Social Sciences and Humanities (MJSSH) \\
\hline Malaysian Journal of & Volume 6, Issue 8, August 2021 \\
\hline (MJ. SSH) & e-ISSN : 2504-8562 \\
\hline & $\begin{array}{l}\text { Journal home page: } \\
\text { www.msocialsciences.com }\end{array}$ \\
\hline
\end{tabular}

\title{
Students' Perception Towards Teaching and Learning of Design and Technology Subject in English
}

\author{
Prabu SN ${ }^{1}$, Nesamalar MK $^{2}$ \\ ${ }^{1}$ Veritas University College (VUC), Malaysia \\ ${ }^{2}$ Macquarie University Australia, Australia \\ Correspondence: Prabu SN (prabu.sn19@gmail.com)
}

\begin{abstract}
This quantitative study aimed to explore the students' perception on the instruction medium of Design and Technology (Reka Bentuk dan Teknologi - RBT) subject in lower secondary forms. This study determined the perceptions of students based on factors such as Students' preferred medium of instruction for RBT, Students' readiness towards English medium instruction (EMI), and Developing English literacy through English medium instruction. This research utilized a survey research design. Online questionnaires constructed for data collection. The target population were 100 public school students in Form One, Two and Three. Findings from the questionnaire exhibits, the participants are favourable on the English medium instruction for RBT curriculum and believe they can benefit from learning RBT in English medium. The outcomes of the study are expected to influence curriculum designers, policymakers, educators and learners on the effectiveness of language in successful RBT pedagogy. In terms of local context, past studies on EMI focused mainly on Science and Mathematics; the traditional STEM subjects. Therefore, this research has the opportunity to fill the gap by including the latest subject, RBT.
\end{abstract}

Keywords: English medium instruction (EMI), Perception, STEM Education

\section{Introduction}

The medium of instruction has constantly stood as a crucial concern among educational institutions across the world. In the Malaysian context, vital measures initially made from the early 1990s to devise English as medium of instruction for the traditional STEM subjects such as Mathematics and Science. The Ministry of Education affirmed STEM education should be conducted in English to accommodate the pupil with the fundamental principles and talents to excel beyond borders (National Education Blueprint, 2013-2025). Apart from preparing 21st-century human resource, this policy is also an anticipated answer to the declining English quality in the country (Kaur, 2020).

As part of new curriculum syllabus, Reka Bentuk dan Teknologi (RBT) introduced in the upper primary and lower secondary schools (National Education Blueprint, 2013-2025). Since the initiation, the National language Bahasa Melayu used as the medium of instruction for teaching the subject. Various studies in the past such as Pillay (2003), Ong and Tan (2008), and Yahaya et al., (2009), have been executed to analyse the significance of English Medium Instructions (EMI) especially for STEM subjects. Studies yet to show interest in the student's perceptions pertaining to the medium of 
instruction. Studies related to students' perceptions of the medium of instruction in STEM subjects, especially RBT, are still limited and minimal in Malaysia.

Therefore, this study can be a new platform and source of reference, especially for STEM and RBT education, to ensure that teaching and learning approaches can be implemented efficiently.

\section{Problem Statement}

Latest findings and discoveries are often documented in English (Phillipson, 2009). English medium instruction (EMI) for STEM education would benefit students to retain the latest scientific and technological knowledge (Ali \& Ismail, 2006). David and Govindasamy (2005), found insufficiency of scientific and technical terms in the Bahasa Melayu and often needed direct translation from English. Nonetheless, Thang and Olaybal (2006) admitted approach to decoding scientific words from English to Bahasa Melayu is not straightforward. Inevitably, when Bahasa Melayu reintroduced in STEM syllabus from 2003, the Malaysian school curriculum encountered a shortage of science and technology study materials in Bahasa Melayu (Thang \& Olaybal, 2006).

Majority of local graduates regularly criticised for their low proficiency in English. Many still have trouble in basic English literacy such as reading, speaking and listening. Inability to rehearse well in the English language, actually affecting their job opportunity (Azman, 2016). This condition forces many graduates not to be competent in the job market, particularly in areas that demand them to master English.

Many studies conducted on RBT teaching and learning in the past focus on the challenges faced by teachers (Ismail, 2012), such as in the implementation process (Isa \& Mohd Imam Ma'arof, 2018), the readiness of teachers for this new subject and factors that contributed to stress among the RBT teachers (Moktar, 2018). Studies have shown teachers encountered challenges in teaching and learning process for this subject (Huei, Rus \& Kamis, 2019). Medium of instruction could be one of the major issue for this struggle. It should not only be viewed from the perspective of educators, but also from the students perspective (Ellili-Cherif \& Alkhateeb, 2015). Yet, there are no known studies on the RBT domain about collecting students' feedback on this subject.

\section{Research Objective}

Following are the specific objectives of this study:

i. Explore the perception of the students on the instruction medium of RBT

ii. Investigate students' readiness to learn STEM in English.

iii. Investigate the role of medium of instruction of RBT in developing English language competency.

\section{Research Questions}

This research was executed to identify students' perceptions about the instruction medium of RBT. The subsequent research questions addressed to find answers to the objectives of the study:

i. What is the students' perception on the language of instruction for RBT?

ii. What is the students' readiness towards learning STEM in English medium?

iii. What is the role of medium of instruction in developing English language competency among RBT students? 


\section{Significance of the Study}

This is a pioneer quantitative study on the language of instruction for RBT. In the past, many studies conducted in Malaysia focusing on the medium of instruction for STEM subjects (Ha, Kho, \& Chng, 2013; Isa et al., 2011; Majid et al., 2011), but no initiation to study the perception of students, especially on RBT.

The available literature on the RBT has focused more on the teachers (Taha, 2014; Abdullah \& Ali, 2017) and teaching methods (Kiong et al., 2018; Isa \& Ma'arof, 2018). The outcomes of present study could benefit academics about the significance of language in RBT pedagogy. Curriculum directors and teachers of STEM subjects might want to consider the students' language preferences and attitudes when developing policies pertaining to the medium of instruction in ensuring students' active participation in the scholarship of teaching and learning.

Exploring students' perspective is necessary since they are directly related in the education process. A review of this research can provide a valuable background for understanding the possible impact of determining whether the Bahasa Melayu should be retained as the RBT medium of instruction, or it would be more suitable to change RBT education to English medium.

The information acquired can function as a crucial practical resource to define the delivery of RBT curriculum. The present study on the influence of the language of instruction in RBT curriculum is proving to be timely and essential.

\section{Literature Review}

Studies about the significance of language in STEM education and students' perception on the medium of instruction are available in (Hudson, 2009), (Kocakulah, Ustunluoglu and Kocakulah, 2005), (Al-Mashikhi, Al-Mahrooqi \& Denman, 2014) and (Basibek et al., 2014). Also, many research has been done locally on the issue of the language of instruction in STEM education (Yunus \& Sukri, 2017; Ismail, 2012 \& Isa, 2011) which suggests that it is not outside the view.

\section{Design and Technology (Reka Bentuk dan Teknologi)}

The Standard Based Curriculum for Secondary School (KSSM), was executed in 2017 to replace the Integrated Secondary School Curriculum (KBSM) (Moktar et al., 2018). Reka Bentuk dan Teknologi (RBT) is the latest addition in the curriculum. It is offered to students of form one, two and three in secondary schools (Ministry of Education, 2015). Via the implementation of RBT, the Ministry of Education Malaysia (MOE) aims to update the older syllabus Kemahiran Hidup Bersatu (KHB) (Sahaat \& Nasri, 2020). It is one of the practical subjects which emphasize integrations of technology in education as the students learn to operate present technologies while focusing on future technological developments (Ismail, 2012). This upgrade is believed to bring changes in line with the government's' aim of producing advanced human models (National Education Blueprint, 2013-2025).

\section{Medium of Instruction and STEM Education in Malaysia}

English as the premium medium of instruction in teaching and learning of STEM is inevitable in many parts of the world. Science and English literacy are inter-related and essential for scholars to compete at the international level (Tuah \& Mohini, 2010). As suggested by Hudson (2009), nations targeting on the 21st-century economic transitions should stress on the growth of the Science Education and English literacy. Considerable researches (Hamid, Jahan \& Islam 2013; Basibek et al. 2014; Kim, Tatar \& Choi 2014) have recommended to embrace English as a medium of instruction for science and technology as there are resources exclusively available in English compared to any other regional languages. 
Malaysia's education system in its inconstancy between the use of Bahasa Melayu and English, particularly in STEM education. Initially the Education Ministry has a rationale in providing Science and Mathematics in English, which is to assist all learners to improve their scientific and English proficiency (Ministry of Education, 2013). Studies also proved this policy has resulted in the mastery of scientific knowledge in related fields and also improved English proficiency among students (Noraini, 2005; Madya et al., 2009). This is because most of the reading material in this fastest growing field are produced in English (Madya et al., 2009; Salbihana, 2006) and disseminated through various media that easily obtainable by the public. More inventions are taking place and access to information in this domain is readily obtainable in English (Phillipson, 2009). Everyone should be opened to the teaching of subjects in English starting from school. Early exposure does provide an excellent opportunity and advantage for students to access the pioneer information.

Gill (2005), have suggested that its optimum to teach STEM in English medium. Melor and Saiful Islam (2017), endorsed the same idea as EMI can facilitate students' understanding. Mendeng and Abdol (2004), assume the restricted usage of Bahasa Melayu in STEM education will benefit the students to face the challenges in mastering English. Consequently, students from the English medium environment will be able to improve language and perform adequately in STEM subjects.

\section{English Medium Instruction and Language Competency}

Studies proved, the EMI policy has several positive influences on students such as improving their language proficiency (Dalton-Puffer, 2011; Yang, 2015; Aguilar \& Rodriguez 2012; Belhiah \& Elhami 2015; Byun et al. 2011), increasing their chances of mobility and employability (Wachter \& Maiworm, 2014), and enhancing their learning motivation (Doiz, Lasagabaster, \& Sierra, 2014).

Ong and Tan (2008) point out the intention of instructing STEM in English promotes students' language proficiency. Teaching STEM in English also set a significant context for natural vocabulary usage to develop the student's language competency. Also, in non-English countries, education in English could offer students better job opportunities and career development (Coleman, 2006). Xu (1991), emphasised that scholars with good command in English embrace the difficulties in studies better than others.

A study was executed by Belhiah and Elhami (2015) to investigate the significance of EMI in the Arabian Gulf. It revealed that the learners and educators register substantial progress in listening, talking, reading, and writing mastery. The research counted EMI policy equips students with adequate, understandable intake in English in terms of genuine English oral and written text. Faizah, Marzlah and Kamaruzman (2011) claimed that EMI has a vital function in expanding learners' language competency. Furthermore, EMI improves the learners' contact hours to the English language and supplement their language command (Ministry of Education, 2013).

In developing countries such as Malaysia, English has been widely used, especially in the field of employment, whether in business or communication alone (Zakaria, 2008). In higher education institutions, the frequency of using English also increases because language is one of the main features of empowering human capital (Ball \& Lindsay, 2013). Knowing the significance of good English fluency, the Education Ministry introduced STEM education in English in intent to enhance the English language among students. Yet, past studies conducted locally (Jalaluddin, 2009; Salam \& Shahrill, 2014) found that the status of English mastery amongst the students remained the same.

\section{Students' Perception on English Medium Instruction}

Studies demonstrate the ability of students to provide insightful reviews involving their learning process in school (Noble, Roberts \& Sawyer, 2006; Robinson \& Taylor, 2007). The research by Rahmadani (2016) examined learners' perception of EMI. The study discovered students maintained favourable perception toward EMI to enhance their English literacy. Likewise, participants in the research of $\mathrm{Wu}$ (2006) commented, EMI was a valuable guideline that allows them to practice English constantly in their school education. Students' readiness to learn is another factor which holds the prospect to impact student accomplishment. 
Past researches have revealed the students in Malaysia recognise the significance of English for the future (Zubairi \& Sarudin). Learners are inspired by elements such as the urge to obtain satisfactory results, possibilities to advance their studies and employment promotion. Racha (2003) investigated the learners' readiness to study Mathematics in English. It concludes the participants were favourable to study the content in the international language. Meanwhile, research by Tuah and Mohini (2010) discovered that learners' readiness, interest and confidence towards EMI is at a moderate level.

Students are analytical and attentive (Rudduck, 2006). They are not to be considered as passive but as active players in improving teaching and learning. The perceptions of students about education, their rationales for studying, the impressions they have, and their reactions may determine how well they will finally comprehend.

\section{Methodology}

The target population of this study was the lower secondary school students in Form 1, 2, and 3. Students from Klang Valley were selected as a smaller group of the target population. The research process required to obtain alternative methods due to the movement control order during the COVID19 pandemic. Given the limitations of the current situation, it was deemed most appropriate to commence the sampling process using the snowball sampling technique. This technique relies on referrals from initially sampled respondents to other persons believed to have the characteristic of interest. Therefore, the researcher chose to examine the perception of the students on medium of instruction for RBT by inviting the students available at the time of questionnaire distribution to help the researcher in responding to the questionnaires.

Section A of this questionnaire sought the demographic details of the respondents. The demographic data included gender, form, language at home, secondary language at home and language proficiency in English. In Section B, 17 items reflecting the 4 factors were highlighted in the conceptual framework. They are Students Readiness Towards Learning STEM in English medium (5 items), Perception Towards Teaching and Learning of RBT in English Medium (4 items) and Bahasa Melayu (4 items) and Developing Language Competency Through EMI (4 items). It featured a five-point Likert Response Scale, with answers varying from 'strongly agree' to 'strongly disagree' and with a neutral option. 1 indicates 'strongly agree' and 5 indicates 'strongly disagree'.

Items in the questionnaire were developed by conferring earlier research related to medium of instruction in STEM education. The items were adaptation of (Isa et al., 2011; Suliman et al., 2017; Yassin et al., 2009 \& Al-Mashikhi et al., 2014). The questionnaire was validated of language before being piloted with a small group of 15 students. Outcomes of the pilot test showed a Cronbach alpha score of 0.746. It indicates a stable and internally consistent instrument.

The online questionnaire was distributed randomly to the students and responses were collected via google drive. In total 100 complete responses were collected. The data in this study were analysed descriptively. All these analyzes use Statistical Package for the Social Sciences (SPSS) version 27. For the items in Section A, frequency and percentage were used to analyse items that were included in the demographic information of respondents. Descriptive statistics developed on each of the 17 individual items in Section B, then classified under their four main headings. They include the mean scores and the frequency distributions for every answer.

\section{Result}

\section{Section A: Demographic Profile of the Sample}

The subjects of this study are 100 lower secondary school students from Form One, Two and Three. Table below show the findings from Section A. They represent the number and percentage of the respondent profile. 
There was an equal number of male and female participants, 50 from each gender from the total respondents. Of the 100 participants, 33 are Form One student, 33 Form Two students, and 34 Form Three students. According to this self-assessment on language proficiency, 25 participants possessed advanced English language skills, 45 students ranked their English proficiency as intermediate, while the remaining 30 students considered their English level to be at the beginner level. The majority of the students speak English as the primary language at home. Followed by Bahasa Melayu, Tamil, and Mandarin. The majority of the students speak English as the secondary language at home. Followed by Bahasa Melayu, Tamil, and Mandarin.

Table 1: Demographic profile $(n=100)$

\begin{tabular}{llc}
\hline \multicolumn{1}{c}{ Category } & \multicolumn{1}{c}{ Item } & $\begin{array}{c}\text { Frequency and Percentage } \\
(\mathbf{\%})\end{array}$ \\
\hline Gender & Male & 50 \\
\multirow{3}{*}{ Form } & Female & 50 \\
& One & 33 \\
& Two & 33 \\
Language at home & Three & 34 \\
& English & 30 \\
& Malay & 28 \\
\multirow{5}{*}{ Second Language at home } & Tamil & 21 \\
& Mandarin & 21 \\
& English & 49 \\
& Malay & 28 \\
\multirow{3}{*}{ English Proficiency } & Tamil & 13 \\
& Mandarin & 10 \\
& Beginning & 30 \\
& Intermediate & 45 \\
& Advanced & 25 \\
\hline
\end{tabular}

\section{Section B: Students' Perception}

A descriptive analysis involved frequency, mean and standard deviation used in order to identify the level of students' perception. The items were classified under their five main headings as shown below.

In this section of the survey, students requested to answer the items on studying STEM in English medium and about their English comprehension such as speaking and reading. The table 2 summaries respondents' readiness to learn STEM in English.

Table 2 : Students' readiness to learn STEM in English

\begin{tabular}{|c|c|c|c|c|c|c|c|c|}
\hline No & Item & $\begin{array}{l}\text { SA } \\
\%\end{array}$ & $\begin{array}{l}\text { A } \\
\%\end{array}$ & $\begin{array}{l}\mathbf{N} \\
\%\end{array}$ & $\begin{array}{l}\text { D } \\
\%\end{array}$ & $\begin{array}{l}\text { SD } \\
\%\end{array}$ & Mean & $\begin{array}{l}\text { Standard } \\
\text { Deviation }\end{array}$ \\
\hline 1. & $\begin{array}{l}\text { I prefer to communicate in } \\
\text { English. }\end{array}$ & 19 & 24 & 25 & 30 & 2 & 2.72 & 1.147 \\
\hline 2. & $\begin{array}{l}\text { I can read instructions and guides } \\
\text { written in English. }\end{array}$ & 28 & 33 & 28 & 10 & 1 & 2.23 & 1.004 \\
\hline 3. & $\begin{array}{l}\text { English is the language of science } \\
\text { and technology. }\end{array}$ & 47 & 38 & 13 & 1 & 1 & 1.71 & 0.808 \\
\hline 4. & $\begin{array}{l}\text { It is appropriate to use English as a } \\
\text { medium of instruction for science } \\
\text { and technology subjects. }\end{array}$ & 51 & 32 & 12 & 4 & 1 & 1.72 & 0.900 \\
\hline 5. & $\begin{array}{l}\text { Studying STEM in English makes } \\
\text { me feel more educated. }\end{array}$ & 57 & 23 & 18 & 1 & 1 & 1.66 & 0.879 \\
\hline
\end{tabular}


Strongly Agree (SA), Agree (A), No Opinion (N), Disagree (D), Strongly Disagree (SD)

\begin{tabular}{llll} 
Factor & Group Mean & Std. Deviation & $\begin{array}{l}\text { Overall } \\
\text { Perception }\end{array}$ \\
Students' Readiness & 2.0080 & 0.73025 & Positive \\
\hline
\end{tabular}

The data shows $43 \%$ of participants agreed with item 1, that English is their preferred language of communication, while $32 \%$ disagreed with it. However, $61 \%$ students can read instructions written in English. And only 11\% have problem reading instructions in English (item 2).

There were $85 \%$ of the students agreed with item 3, that English is the principal language of science and technology. Among them, $83 \%$ believe it is significant to study science in English medium (item 4). Finally, $83 \%$ students accept the statement, "Studying STEM in English makes me feel more educated."

Based on the results on table 2, the students generally have a positive attitude towards EMI. This also means that they value the English language and tend to respond favorably to it. The group mean of 2.01 indicates the students believe they are ready to learn the subject in English.

Table 3 : Students' perception toward learning RBT in English

\begin{tabular}{|c|c|c|c|c|c|c|c|c|}
\hline No & Item & $\begin{array}{l}\text { SA } \\
\%\end{array}$ & $\begin{array}{l}\text { A } \\
\%\end{array}$ & $\begin{array}{l}\mathbf{N} \\
\%\end{array}$ & $\begin{array}{l}\mathrm{D} \\
\%\end{array}$ & $\begin{array}{l}\text { SD } \\
\%\end{array}$ & Mean & $\begin{array}{l}\text { Standard } \\
\text { Deviation }\end{array}$ \\
\hline 6. & I like learning RBT in English. & 21 & 37 & 27 & 13 & 2 & 2.38 & 1.023 \\
\hline 7. & $\begin{array}{l}\text { Resources for RBT, e.g., textbooks } \\
\text { and reference books, are more in } \\
\text { English than in Malay. }\end{array}$ & 67 & 22 & 7 & 4 & 0 & 1.48 & 0.797 \\
\hline 8. & $\begin{array}{l}\text { Learning RBT in English is useful } \\
\text { for my future. }\end{array}$ & 26 & 42 & 27 & 5 & 0 & 2.11 & 0.852 \\
\hline 9. & $\begin{array}{l}\text { Studying RBT in English is } \\
\text { necessary to continue my studies at } \\
\text { tertiary level. }\end{array}$ & 31 & 33 & 29 & 7 & 0 & 2.12 & 0.935 \\
\hline
\end{tabular}

Strongly Agree (SA), Agree (A), No Opinion (NO), Disagree (D), Strongly Disagree (SD)

\begin{tabular}{llll}
\hline Factor & Group Mean & Std. Deviation & $\begin{array}{l}\text { Overall } \\
\text { Perception }\end{array}$ \\
\hline $\begin{array}{l}\text { RBT in English Medium of } \\
\text { Instruction }\end{array}$ & 2.0225 & 0.65914 & Positive \\
\hline
\end{tabular}

In this part of the survey, students were asked if they preferred the RBT instruction to be conducted in English. The table 3 summarises students' perception on learning RBT in English medium. The data show that $58.0 \%$ of participants agreed they like learning RBT in English, while 15\% disagreed with the statement. There were $89 \%$ of the students believes more resources for RBT available in English compare to Bahasa Melayu. Majority of the students agreed learning RBT in English is useful for their future (68\%) and tertiary education (64\%). Based on the results and on table 3, English is the preferred medium of instruction for RBT subject. The group mean of 2.02 strongly indicates the students' preference to learn the subject in English compare to other language.

Table 4 : Students' perception toward learning RBT in Bahasa Melayu

\begin{tabular}{lllllllll}
\hline No & Item & SA & A & N & D & SD & Mean & $\begin{array}{l}\text { Standard } \\
\text { Deviation }\end{array}$ \\
\hline $\mathbf{1 0 .}$ & $\begin{array}{l}\text { I prefer using Malay as a medium } \\
\text { of instruction for RBT. }\end{array}$ & 18 & 31 & 12 & 20 & 19 & 2.91 & 1.415 \\
\hline
\end{tabular}



DOI: https://doi.org/10.47405/mjssh.v6i8.970

\begin{tabular}{lllllllll}
\hline 11. & $\begin{array}{l}\text { Malay is more effective as a } \\
\text { medium of instruction for RBT } \\
\text { than English. }\end{array}$ & 6 & 19 & 17 & 23 & 35 & 3.62 & 1.301 \\
\hline 12. & $\begin{array}{l}\text { I can spend less time on my } \\
\text { studies if I study all subjects in } \\
\text { Malay rather than in English. }\end{array}$ & 18 & 20 & 30 & 13 & 19 & 2.95 & 1.351 \\
\hline 13. & $\begin{array}{l}\text { If I study RBT in Malay, my } \\
\text { family members can give me } \\
\text { more help. }\end{array}$ & 19 & 10 & 17 & 19 & 35 & 3.41 & 1.518 \\
\end{tabular}

Strongly Agree (SA), Agree (A), No Opinion (NO), Disagree (D), Strongly Disagree (SD)

\begin{tabular}{llll}
\hline Factor & Group Mean & Std. Deviation & $\begin{array}{l}\text { Overall } \\
\text { Perception }\end{array}$ \\
\hline $\begin{array}{l}\text { RBT in Malay Medium of } \\
\text { Instruction }\end{array}$ & 3.2225 & 1.03408 & Neutral \\
\hline
\end{tabular}

In this part of the survey, students were asked if they preferred instruction to be conducted in Bahasa Melayu. The table 4 summarises students' attitudes towards Malay medium learning for RBT. The mean score for this section is 3.22 , that indicate the mixed opinion among the students towards learning RBT in Bahasa Melayu.

The data shows nearly half of the respondence (49\%), prefer Bahasa Melayu as a medium of instructions but only 25\% agree "Bahasa Melayu is more effective than English as medium of instruction for RBT". In terms of time management and support from family members, the study shows mixed opinions from the students.

Based on the results and on table 4, the findings show no significant advantage of learning RBT in Bahasa Melayu. The group mean of 3.22 indicates the students do not recognise Bahasa Melayu as the preferred medium to learn the subject.

Table 5 : Role of RBT in developing English language competency

\begin{tabular}{|c|c|c|c|c|c|c|c|c|}
\hline No & Item & $\begin{array}{l}\text { SA } \\
\%\end{array}$ & $\begin{array}{l}\mathbf{A} \\
\%\end{array}$ & $\begin{array}{l}\mathbf{N} \\
\%\end{array}$ & $\begin{array}{l}\text { D } \\
\%\end{array}$ & $\begin{array}{l}\text { SD } \\
\%\end{array}$ & Mean & $\begin{array}{l}\text { Standard } \\
\text { Deviation }\end{array}$ \\
\hline 14. & $\begin{array}{l}\text { EMI motivate me to improve my } \\
\text { English. }\end{array}$ & 28 & 56 & 12 & 2 & 2 & 1.94 & 0.814 \\
\hline 15. & $\begin{array}{l}\text { EMI help me to improve my } \\
\text { English reading and writing } \\
\text { abilities.. }\end{array}$ & 30 & 49 & 15 & 5 & 1 & 1.98 & 0.864 \\
\hline 16. & $\begin{array}{l}\text { EMI help me to improve my } \\
\text { English listening and speaking } \\
\text { abilities. }\end{array}$ & 29 & 35 & 26 & 7 & 3 & 2.20 & 1.035 \\
\hline 17. & $\begin{array}{l}\text { I learn new vocabularies every time } \\
\text { my teacher used English in } \\
\text { classroom }\end{array}$ & 25 & 40 & 28 & 6 & 1 & 2.18 & 0.914 \\
\hline
\end{tabular}

Strongly Agree (SA), Agree (A), No Opinion (NO), Disagree (D), Strongly Disagree (SD)

\begin{tabular}{llll} 
Factor & Group Mean & Std. Deviation & $\begin{array}{l}\text { Overall } \\
\text { Perception }\end{array}$ \\
\hline Language Competency & 2.0750 & 0.77809 & Positive \\
\hline
\end{tabular}


In the last part, participants were asked to rank their agreement for several ideas associated with perceived progress in English language competency. The table 5 displays the students' perception towards language competency development through learning RBT in English.

The mean score 2.08 indicates a positive relation. 84\% students agree EMI motivate them to improve English. Item 15 and 16, indicates EMI can improve reading, writing, listening and speaking ability. Majority of the students learn new vocabulary through English medium lessons.

Based on the results and on table 5, medium of instruction can influence the language competency of the students. The group mean of 2.08 indicates English language competency improve through learning RBT in English.

Table 6 : Summary of findings

\begin{tabular}{|c|c|c|}
\hline Research Question & $\begin{array}{l}\text { Data Analysis } \\
\text { Method }\end{array}$ & Results \\
\hline $\begin{array}{l}\text { 1. What is the students' readiness } \\
\text { towards learning STEM in } \\
\text { English medium? }\end{array}$ & $\begin{array}{l}\text { Mean, Standard } \\
\text { deviation }\end{array}$ & $\begin{array}{l}\text { Students able to read and write in } \\
\text { English. } \\
\text { Motivated to study STEM in English }\end{array}$ \\
\hline $\begin{array}{l}\text { 2.What is the students' } \\
\text { impression on language of } \\
\text { instruction for RBT? }\end{array}$ & $\begin{array}{l}\text { Mean, Standard } \\
\text { deviation }\end{array}$ & $\begin{array}{l}\text { Students can collect more study materials } \\
\text { in English than in Bahasa Melayu. } \\
\text { Perceive EMI benefits their further } \\
\text { studies and job. }\end{array}$ \\
\hline $\begin{array}{l}\text { 3. What is the role of medium of } \\
\text { instruction in developing English } \\
\text { language competency among }\end{array}$ & $\begin{array}{l}\text { Mean, Standard } \\
\text { deviation }\end{array}$ & $\begin{array}{l}\text { EMI addresses positive perception of } \\
\text { students' reading, writing, listening and } \\
\text { speaking abilities. }\end{array}$ \\
\hline RBT students? & & $\begin{array}{l}\text { Students' English competency develops } \\
\text { by studying RBT in English medium. }\end{array}$ \\
\hline
\end{tabular}

\section{Discussion}

This study sought to explore students' perceptions on the instruction medium of Design and Technology (Reka Bentuk dan Teknologi) in lower secondary schools. The discussion that proceeds concerns with reporting the findings of the research questions in the study.

\section{Readiness to Learn STEM in English}

Results from the questionnaire show that the students prepared to learn STEM in English. This finding is also consistent reported by Ball and Lindsay (2013); Costa and Coleman (2013). They have indicated students' positive attitudes towards EMI. The study of Rahmadani (2016) investigated students' perception of EMI and found out that most students prefer English medium, especially in science and technology subjects (Usunier \& Roulin, 2010). Likewise, students in the study of Wu (2006) expressed that EMI is a beneficial procedure which allows learners to use English to study science and technology subjects and benefits learning process. Additionally, most of the respondents in the present study regarded themselves could read, write or speak English confidently. The results also highlight those respondents with good English literacy were positive towards English medium instruction.

\section{RBT Language of Instruction}

The research indicated that most of the students regarded they could profit from learning RBT in English medium. This is illustrated by Tuah and Mohini (2010); Coleman (2006). that EMI is essential for the career workforce in future. One of the motives for teaching and learning STEM in English is to deliver possibilities for learners to engage in the use of the language. Additionally, the majority of the students disagreed about learning RBT in Bahasa Melayu. 
Undeniably, students believe that they learn RBT better in the English language than Bahasa Melayu. Likewise, a study by Suliman, Melor and Saiful Islam (2017) also delivered similar findings as that studying STEM in English does promote students' learning process better compared to Bahasa Melayu. Availability of study materials such as reference books, textbooks and online resources play an essential role in the selection of the medium of instruction for students in this study. Most of the sources of Science knowledge are produced in English (Phillipson, 2009). This view is consistent with what has been observed in Hamid, Jahan and Islam (2013) and Basibek et al. (2014). Additionally, Kim, Tatar and Choi (2014), mentioned the reality of the English language only study materials and insufficient support in the Bahasa Melayu.

\section{Developing English Competency}

This study also revealed, students believed that their English language proficiency improves by learning STEM subjects in English. Similarly, studies surveying participants beliefs have registered favourable reactions to the significance of EMI in enhancing their English (Aguilar \& Rodriquez 2012; Belhiah \& Elhami 2015; Byun et al., 2011). As summarised in prior research, including Pandian and Ramiah (2004), EMI is practical for meaningful developments and adequate understandings in the learning of the second language. EMI courses should be seen as a chance to improve students' mastery of the English language (Wu, 2006). In the study of Rahmadani (2016) most learners had favourable perception toward English medium instruction, which assist them in enhancing their English literacy skills and confidence to voice out in public and comprehend English writings such as textbook or article.

Additionally, Ong and Tan (2008) pointed out the objective of teaching STEM in English is to allow students to attain proficiency in the language. Thereby, it should be concluded that instructing STEM in English would set a meaningful context for natural language usage. Therefore, serve a decisive point by significantly growing oral language and literacy. Faizah, Marzilah and Kamaruzaman (2011) added, studying non-language subjects in English increases students' contact hours to the English language, hence develop students' language competency. Moreover, Belhiah and Elhami (2015) study revealed that most learners and educators register significant progress in listening, talking, reading, and essay writing in English. They added, EMI provides students with substantial comprehensible input in English.

\section{Limitation}

The current respondents only represent participants from 3 districts in Selangor. In the light of current study results, it can only be concluded to Klang Valley students. On the other side, it was small scale research that comprised 100 students only. Thus, it is recommended that a more significant sample size should be retained for the forthcoming studies for the results to be generalised to a more considerable population and better representation.

For future research, in line with the government's recent emphasis on STEM education, a follow-up study to determine RBT teachers, educational leaders, and curriculum designers' attitude towards teaching and learning in English in Malaysia should be conducted to investigate the general mood. Further studies will help students in this nation to have optimistic attitudes towards EMI and realise the importance of teaching and learning STEM in the English language.

\section{Recommendation}

Overall, the participants acknowledge the necessity for the change in the medium of instruction. Therefore, measures must be taken to support the teaching and learning of RBT in English. This will allow the relevant stake holders to further explore and sustain the teaching of STEM subjects in the English language medium of instruction. 
STEM educators, academic directors, and curriculum developers should consider the students' English language proficiency when designing curriculum for STEM subjects. Findings of this study have evinced that students do indeed demonstrate positive perception and acceptance of learning RBT (and in that extension, STEM) subjects using the English language medium of instruction. Continuity on such scholarship of teaching and learning further promotes students' potential projection into furthering their studies abroad. This is of particular importance given that the nation is progressively moving forward with transnational education.

\section{Conclusion}

Students demonstrated their views by strongly indicating English is a suitable medium to learn RBT. The findings of this study suggest that students view English as a universal language and very essential for STEM education. The objective of orienting English as the medium of instruction is primarily to allow learners to sustain the evolutions of science and technology. EMI helps students to obtain the latest and advance knowledge about science and technology, which is available predominantly in the English language (Yahaya et al., 2009). Learning STEM in the English language enables students to explore the knowledge globally and at the same time, increases the potential of the students in the workforce. Students in this study were aware that English is the language of science and technology.

Perception of the significance of a particular language is subject to many aspects. Society will display a favourable mindset toward a specific language if that language has economic importance and is accepted as being reputable. This study has revealed the participants prefer English as the medium of instruction for RBT. Overall, the students agreed they are prepared to learn RBT through the English language.

\section{References}

Abd Salam, N. H., \& Shahrill, M. (2014). Examining classroom interactions in secondary mathematics classrooms in Brunei Darussalam. Asian Social Science, 10(11), 92.

Abdullah, N., \& Ali, A. (2017). Tahap Kesediaan Guru Pelatih Reka Bentuk Dan Teknologi Terhadap Pengajaran Mata Pelajaran Reka Cipta. Online Journal for TVET Practitioners, 2(1). Retrieved from https://publisher.uthm.edu.my/ojs/index.php/oj-tp/article/view/4763

Aguilar, M., \& Rodriguez, R. (2012). Lecturer and student perceptions on CLIL at a Spanish university. International Journal of Bilingual Education and Bilingualism, 15(2), 183-197.

Ali, M., \& Ismail, Z. (2006). Comprehension level of non-technical terms in science: are we ready for science in English. Malaysian Journal of Educators and Education, 21, 73-83.

Al-Masheikhi, F., Al-Mahrooqi, R., \& Denman, C. J. (2014). Investigating college of science student attitudes towards using English as a medium of instruction. In The 2014 WEI International Academic Conference Proceedings (pp. 99-113).

Azman, H. (2016). Implementation and challenges of English language education reform in Malaysian primary schools. 3 L: Language, Linguistics, Literature

Ball, P. and Lindsay, D., 2013. Language demands and support for English-medium instruction in tertiary education. Learning from a specific context. English-medium instruction at universities: Global challenges, 4466.

Başıbek, N., Dolmacı, M., Cengiz, B. C., Bür, B., Dilek, Y., \& Kara, B. (2014). Lecturers' perceptions of English medium instruction at engineering departments of higher education: A study on partial English medium instruction at some state universities in Turkey. Procedia-Social and Behavioral Sciences, 116, 1819-1825.

Belhiah, H., \& Elhami, M. (2015). English as a medium of instruction in the Gulf: When students and teachers speak. Language Policy, 14(1), 3-23.

Byun, K., Chu, H., Kim, M., Park, I., Kim, S., \& Jung, J. (2011). English-medium teaching in Korean higher education: Policy debates and reality. Higher Education, 62(4), 431-449. 
Coleman, J. A. (2006). English-medium teaching in European higher education. Language teaching, 39(1), 1-14.

Costa, F., \& Coleman, J. A. (2013). A survey of English-medium instruction in Italian higher education. International journal of bilingual education and bilingualism, 16(1), 3-19.

David, M. K., \& Govindasamy, S. (2005). Negotiating a National Language Policy: Local Need for Affirmative action versus commitment towards globalization. Reclaiming the local in language policy and practice. Mahwah NJ: Lawrence Erlbaum, 123-146.

Doiz, A., Lasagabaster, D., \& Sierra, J. M. (2014). CLIL and motivation: The effect of individual and contextual variables. The language learning journal, 42(2), 209-224.

Ellili-Cherif, M., \& Alkhateeb, H. (2015). College students' attitude toward the medium of instruction: Arabic versus English dilemma.

Gill, S. K. (2005). Language policy in Malaysia: Reversing direction. Language policy, 4(3), 241-260.

Government of Malaysia (GoM) (2013). Malaysia Education Blueprint: 2013-2025. Putrajaya: Economic Planning Unit.

Hamid, M. O., Jahan, I., \& Islam, M. M. (2013). Medium of instruction policies and language practices, ideologies and institutional divides: Voices of teachers and students in a private university in Bangladesh. Current Issues in Language Planning, 14(1), 144-163.

Hudson, P. (2009). Learning to teach science using English as the medium of instruction. Eurasia Journal of Mathematics, Science and Technology Education, 5(2), 165-170.

Huei, O. K., Rus, R. C., \& Kamis, A. (2019). Need Analysis: Competency Development Measurement Instrument in Mastering the Content of Design and Technology Subject in High School. International Journal of Academic Research in Business and Social Sciences, 9(6), 1043-1052.

Isa, N. S., \& Ma'arof, N. N. M. I. (2018). Keberkesanan penggunaan grafik berkomputer sebagai alat bahan bantu mengajar dalam kalangan pelajar reka bentuk dan teknologi. Sains Humanika, 10(3-3).

Isa, Z., Zakaria, A. M., Azlan, M. I., Noorani, M. S. M., Majid, N., Ismail, H., ... \& Suradi, N. R. M. (2011). Students' perceptions of the implementation of teaching and learning of Science and Mathematics in English. Procedia-Social and Behavioral Sciences, 18, 361-366.

Ishak, T., \& Mohamed, M. (2010). Pengajaran dan pembelajaran sains dan matematik dalam bahasa inggeris (PPSMI): Suatu isu berulang. Sains Humanika, 53(1).

Ismail, S. (2012). Kesediaan guru terhadap pelaksanaan mata pelajaran Reka Bentuk dan Teknologi (RBT) sekolah rendah di Malaysia (Doctoral dissertation, Universiti Tun Hussein Onn Malaysia).

Jalaluddin, N. H., \& Syah, A. H. (2009). Penelitian makna imbuhan Pen-Dalam Bahasa Melayu: Satu kajian rangka rujuk silang. GEMA Online ${ }^{\circledR}$ Journal of Language Studies, 9(2).

Kaur, K. (2020, February 5). PPSMI: Why Malaysian Education System Keeps Switching Languages. TRP. https://www.therakyatpost.com/2020/02/04/kabhi-malay-kabhi-english-a-history-oflanguage-in-malaysias-education-system/

Kim, J., Tatar, B., \& Choi, J. (2014). Emerging culture of English-medium instruction in Korea: experiences of Korean and international students. Language and Intercultural Communication, 14(4), 441-459.

Kiong, T. T., Saien, S., Yunos, J. M., Heong, Y. M., Mohamad, M. M., Azman, M. N. A., \& Hanapi, Z. (2018). Teori PenyelesaianMasalah Inventif (TRIZ) Bagi Matapelajaran Reka Bentuk Dan Teknologi. Online Journal for TVET Practitioners.

Kocakulah, S., Ustunluoglu, E., \& Kocakulah, A. (2005, December). The effect of teaching in native and foreign language on students' conceptual understanding in science courses. In Asia-Pacific Forum on Science Learning and Teaching (Vol. 6, No. 2, pp. 1-30). The Education University of Hong Kong, Department of Science and Environmental Studies.

Kementerian Pendidikan Malaysia (2015) 'Kurikulum Standard Sekolah Menengah Reka Bentuk dan Teknologi Dokumen Standard Kurikulum dan Pentaksiran Tingkatan 1'.

Lan, O. S., \& Tan, M. (2008). Mathematics And Science in English: Teachers Experience Inside the Classroom. Journal of Educators \& Education/Jurnal Pendidik dan Pendidikan, 23. 
Le Ha, P., Kho, J., \& Chng, B. (2013). Nation building, English as an international language, medium of instruction, and language debate: Malaysia and possible ways forward. Journal of International and Comparative Education (JICE), 58-71.

Madya, D., Buntat, Y., Saud, M. S., \& Ahmad, S. F. (2018). Masalah Pembelajaran Matematik Tahun Lima Dalam Bahasa Inggeris.

Majid, N., Jaaman, S. H., Darus, M., Nazar, R. M., Ramli, S. N. M., Suradi, N. R. M., ... \& Ali, Z. M. (2011). The readiness of mathematics and science lecturers to teach in English from students' perspective. Procedia-Social and Behavioral Sciences, 18, 342-347.

Malaysia, K. P. (2015). Pelan Pembangunan Pendidikan Malaysia 2015-2025 (Pendidikan Tinggi). Putrajaya, Malaysia: Kementerian Pendidikan Malaysia.

Mendeng, J., \& Abdol, M. J. (2004). Pelaksanaan Pengajaran Sains Dan Matematik Dalam bahasa Inggeris: Tinjauan Pada Persepsi Pelajar Di Tiga buah Sekolah Sekitar Daerah Kota Kinabalu, Sabah (Doctoral dissertation, Universiti Teknologi Malaysia).

Mohd Taha, N. (2014). Stres guru yang mengajar subjek Reka Bentuk dan Teknologi (RBT) di sekolah rendah di Kuantan (Doctoral dissertation, Universiti Tun Hussein Onn Malaysia).

Moktar, S. N. A., Hanapi, Z., Kiong, T. T., Mohamed, S., \& Rus, R. C. (2018). Kesediaan, Penerimaan Dan Pengoperasian Guru Reka Bentuk dan Teknologi Terhadap Amalan dalam Pentaksiran Berasaskan Sekolah. Sains Humanika, 10(3-3).

Noble, J. P., Roberts, W. L., \& Sawyer, R. L. (2006). Student Achievement, Behavior, Perceptions, and Other Factors Affecting ACT Scores. ACT Research Report Series, 2006-1. ACT, Inc.

Nor, F. M., Aziz, M. A., \& Jusoff, K. (2011). Should English for teaching mathematics and science (ETeMS) in Malaysia be abolished. World applied sciences journal, 12(Special Issue on Creating a Knowledge Based society), 36-40.

Pandian, A., \& Ramiah, R. (2004). Mathematics and science in English: Teacher voice. The English Teacher, 33(11), 2004-2050.

Phillipson, R. (2009). English in globalisation, a Lingua Franca or a Lingua Frankensteinia?. TESOL Quarterly, 43(2), 335-339.

Pillay, H. (2003). Winds of change: Teaching Science and Mathematics in English-A perspective from the school. IPBA e-Journal, 1-5.

Racha, N. (2003). A survey on the readiness of students to learn Mathematics in English. Unpublished BA thesis, University Kebangsaan Malaysia, Bangi, Malaysia.

Rahmadani, D. (2016). Students' perception of English as a medium of instruction (EMI) in English classroom. Journal on English as a foreign language, 6(2), 131-144.

Robinson, C., \& Taylor, C. (2007). Theorizing student voice: Values and perspectives. Improving schools, 10(1), 5-17.

Rudduck, J. (2006). The past, the papers and the project. Educational Review, 58(2), 131-143.

Sahaat, Z., \& Nasri, N. M. (2020). Cabaran Pelaksanaan Mata Pelajaran Reka Bentuk dan Teknologi Sekolah Menengah (Challenges in the Implementation of Design and Technology Subject in Secondary School). Jurnal Pendidikan Malaysia (Malaysian Journal of Education), 45(1SI), 51-59.

Suliman, A., Nor M. Y. M., \& Yunus, M. M. (2017). Dual-language programme in Malaysian secondary schools: Glancing through the students' readiness and unravelling the unheard voices. GEMA Online ${ }^{\circledR}$ Journal of Language Studies, 17(4).

Thang, S. M., \& Olaybal, D. L. (2006). Creating And Testing a Science in English Website For Malaysian Secondary One Students. Malaysian Online Journal of Instructional Technology (MOJIT), 3(1), 36-42.

Usunier, J. C., \& Roulin, N. (2010). The influence of high-and low-context communication styles on the design, content, and language of business-to-business web sites. The Journal of Business Communication (1973), 47(2), 189-227.

Wachter, B., \& Maiworm, F. (Eds.). (2014). English-taught programs in European higher education: The state of play in 2014. Lemmens Medien GmbH.

Wu, W. S. (2006). Students' attitudes toward EMI: Using Chung Hua University as an example. Journal of Education and Foreign Language and Literature, 4, 67-84.

$\mathrm{Xu}$, M. (1991). The impact of English-language proficiency on international graduate students' perceived academic difficulty. Research in Higher Education, 32(5), 557-570. 
Yahaya, M. F. B., Noor, M. A. B. M., Mokhtar, A. A. B., Rawian, R. B. M., Othman, M. B., \& Jusoff, K. (2009). Teaching of Mathematics and Science in English: The Teachers' Voices. English Language Teaching, 2(2), 141-147.

Yassin, S. M., Marsh, D., Tek, O. E., \& Ying, L. Y. (2009). Learners' perceptions towards the teaching of science through English in Malaysia: A quantitative analysis. International CLIL Research Journal, 1(2), 54-69.

Yunus, M. M., \& Sukri, S. I. A. (2017). The Use of English in Teaching Mathematics and Science: The PPSMI Policy vis-à-vis the DLP. Advances in Language and Literary Studies, 8(1), 133142.

Zubairi, A. M., \& Sarudin, I. H. (2009). Motivation to learn a foreign language in Malaysia. GEMA Online Journal of Language Studies, 9(2). 